\title{
Effect of Torrefaction Temperature, Residence Time and Particle Size on the Properties of Torrefied Food Waste
}

\author{
Ruwaida Abdul Rasid*, Thye Mei Chin, Mazni Ismail, and Rahsya Nur Udzaifah Abdul Rahman \\ Faculty of Chemical and Natural Resources Engineering, Universiti Malaysia Pahang, \\ Lebuhraya Tun Razak 26300, Gambang, Pahang, Malaysia
}

* Corresponding author:

tel: $+6013-3669874$

email:ruwaida@ump.edu.my

Received: August 3, 2018

Accepted: November 14, 2018

DOI: $10.22146 /$ ijc.39718

\begin{abstract}
Municipal solid waste (MSW) in Malaysia mainly consists of food waste. As food waste is of organic compounds, its improper management may cause serious environmental issues, as it may produce greenhouse gases and polluting leachate. Alternative management of food waste is through its utilization. However, the main issue in the utilization of food waste is its heterogeneity, whereby the diversified cooking methods, as well as food origin, emanates different characteristics. Hence, food waste needs to be pre-treated through the torrefaction process, which is a thermochemical method that converts it to biochar at a temperature between $200-300{ }^{\circ} \mathrm{C}$ in an inert environment. The main aim of this work is to evaluate the feasibility of food waste as a potential source of energy through the torrefaction process. The torrefaction of food waste was conducted in a vertical tubular reactor under an inert atmosphere. The results obtained from this study showed that as torrefaction temperature became more severe, the produced torrefied solid is more energy-dense, with apparent higher fixed carbon content and improved heating values. These findings imply that food waste may be able to be utilized as a solid biofuel, with fuel properties comparable to conventional fuels.
\end{abstract}

Keywords: food waste; biomass; torrefaction; higher heating value; mass yield

\section{- INTRODUCTION}

Food waste (FW) represents a significant fraction of municipal solid waste (MSW), whereby of the 25,000 metric ton of wastes collected daily, $45 \%$ are of organics sources [1]. It is the main cause of smell and nuisance on top of the formation of polluting leachate which may lead to the contamination of soil, water, and air. FW is mainly composed of organic materials, which includes waste from food preparation, as well as leftovers. Each day Malaysians produced 38 thousand tonnes of solid wastes whereby, food waste contributed around 39\%, although, 3,000 tonnes of food waste were avoidable [2].

Food waste can be highly variable depending on their sources, whereby it is characterized by having high moisture content and high volatile solids to total solids ratio [3]. Furthermore, food waste has a low higher heating value (HHV), low energy density levels compared to conventional fuels [3]. This is a clear indication of the need for having to pre-treat the food waste prior to its utilization. This may be realized through the cutting edge thermochemical technology, known as the torrefaction process. Torrefaction is a thermochemical pre-treatment that converts biomass wastes into biochar at a relatively low temperature of $200-300{ }^{\circ} \mathrm{C}$ in an inert environment. Through this process, food waste will be thermally treated to improve its physical properties such that the energy density of the food waste will increase and its moisture content will decrease.

Only a handful of work has been carried out with regards to the torrefaction of $\mathrm{FW}$, compared to pyrolysis and gasification. Poudel et al. [4] studied the torrefaction of Korean food wastes, while Jo et al. [5] studied the pyrolysis of simulated food waste as opposed to actual food wastes. Meanwhile, Samad et al. [6] studied the torrefaction of the municipal solid wastes such as the FW and wood waste. Hence, the aim of this study is to evaluate the potential of the utilization of FW that is a significant portion of MSW as an energy source through 
torrefaction, focusing on the effect of temperature, residence time and particle size.

\section{- EXPERIMENTAL SECTION}

\section{Materials}

Food waste was collected from Sungai Ikan landfill in Kuala Terengganu, Malaysia. The samples were dried in an oven at $105^{\circ} \mathrm{C}$ for $24 \mathrm{~h}$ in the Faculty of Chemical Engineering \& Natural Resources laboratory, Universiti Malaysia Pahang to reduce its moisture. They were then grounded and sieved to ensure consistent particle sizes.

\section{Instrumentation}

A tubular reactor was set for the torrefaction process with the schematic diagram as shown in Fig. 1. Instrumentations were used, i.e., Thermogravimetry Analyzer (TGA) model STA7200 by using software TA7000 (CARIFF Universiti Malaysia Pahang/UMP) and CHNS Element Analyzer Macro Elemental (Central Laboratory of UMP).

\section{Procedure}

For the torrefaction process, $3 \mathrm{~g}$ of food waste powder was placed in a tubular reactor. Nitrogen gas was then allowed to purge flown through the reactor for approximately $3 \mathrm{~min}$ at a flow rate of $10 \mathrm{~mL} / \mathrm{min}$ to ensure inert atmosphere. The furnace temperature was set to be varied between 280 to $320^{\circ} \mathrm{C}$. The experiment starts once the furnace temperature reached the desired temperature, for various residence times, after which, the reactor was allowed to cool for 5 before samples recovery. The experiment was repeated by using different particle sizes ( $>1,1$ and $0.5 \mathrm{~mm}$ ).

The dried food waste samples and the torrefied products were analyzed in a TGA - STA7200 to determine the moisture content (MC), volatile matter (VM), fixed carbon (FC) and ash content. Besides that, the elemental analysis was obtained by CHNS Element Analyzer Macro Elemental to determine the weight percentage of elemental carbon, hydrogen, nitrogen, sulfur, and oxygen (by difference) in the samples. Furthermore, heating value is calculated based on the formula [7] by using the results of weight percentages of the elemental carbon, hydrogen, nitrogen, sulfur, and oxygen obtained from CHNS Element Analyzer as shown in Eq. 1:

$$
\begin{aligned}
\mathrm{HV}\left(\frac{\mathrm{MJ}}{\mathrm{kg}}\right)= & 0.3491 \mathrm{C}+1.1783 \mathrm{H}+0.1005 \mathrm{~S}-0.1034 \mathrm{O} \\
& -0.0151 \mathrm{~N}-0.0211 \mathrm{~A}
\end{aligned}
$$

where $\mathrm{C}, \mathrm{H}, \mathrm{O}, \mathrm{N}$ are the elemental compositions which are carbon, hydrogen, oxygen, and nitrogen respectively.

The mass yield, $\mathrm{Y}_{\mathrm{m}}$ is obtained from the percentage of mass left after biomass underwent mass loss as shown in Eq. 2.

$$
\mathrm{Y}_{\mathrm{m}}=100-\left[\frac{\text { Initial Mass }- \text { Final Mass }}{\text { Initial Mass }} \times 100\right]
$$

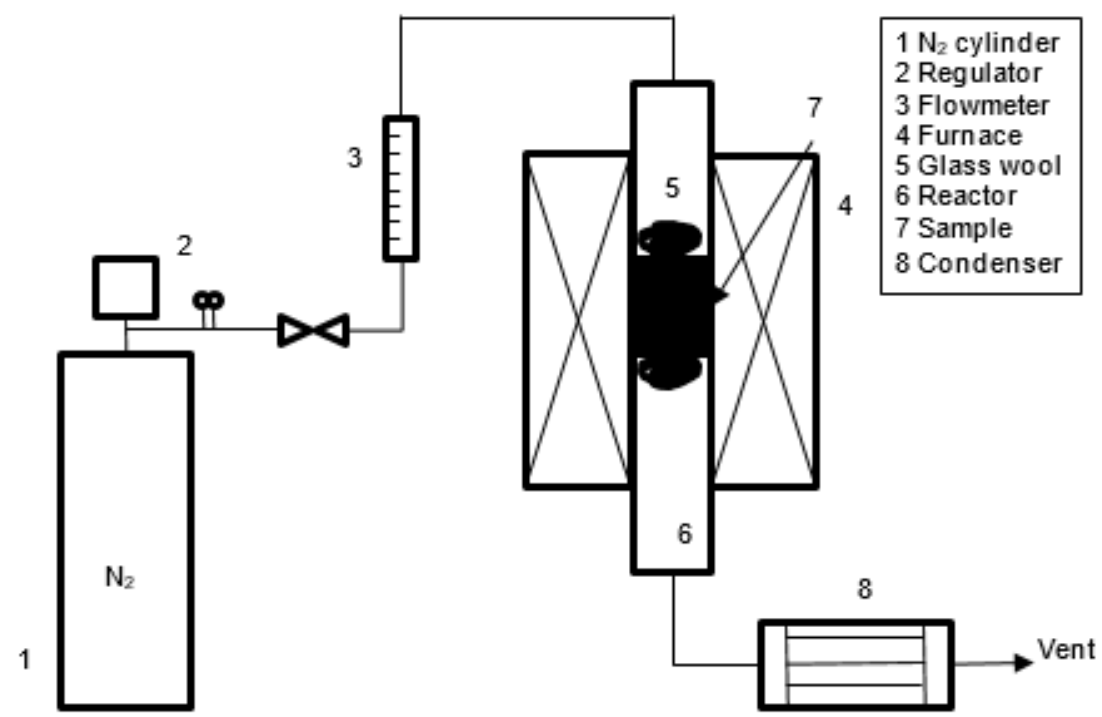

Fig 1. Simplified schematic diagram of experimental design 
In addition, the degree of torrefaction, $\mathrm{T}_{\mathrm{d}}$ were also determined based on Eq. 3 [8] based on the HHV of raw and treated samples.

$$
\mathrm{T}_{\mathrm{d}}=\frac{\mathrm{HHV}_{\text {torr }}}{\mathrm{HHV}_{\text {raw }}}
$$

where $\mathrm{HHV}_{\text {torr }}$ and $\mathrm{HHV}_{\text {raw }}$ are the $\mathrm{HHV}$ of torrefied food waste and HHV of raw food waste respectively. The degree of torrefaction indicates the relative energy gained per unit mass of the torrefied biomass in comparison to its raw, untreated form.

Table 1 is the characterization of the raw food waste sample used in this work in terms of the proximate analysis, ultimate analysis and the HHV of the sample. As can be seen in the table, the volatile matter (VM) of the sample was high at $81 \%$, and the fixed carbon (FC) was really low at only $3.77 \%$, both of which are undesirable characteristics of solid fuel.

\section{- RESULTS AND DISCUSSION}

\section{Mass Yield}

The mass yield of torrefied food waste was calculated based on Eq. 2, and the results are presented in Fig. 2 to illustrate the effects of temperature, residence time and particle size towards solid yield after the samples undergone torrefaction. It was found that there was a reduction in mass yield as torrefaction temperature increased, residence time increased and as the particle size reduced, as shown in the figure. The large particle size of $>1 \mathrm{~mm}$ at $280^{\circ} \mathrm{C}$ and $15 \mathrm{~min}$ residence time produced the highest mass yield of $68.11 \%$, followed by $1 \mathrm{~mm}$ particle size at similar torrefaction temperature and residence time, at $58.62 \%$. The mass yields then continue to decrease with further increase in torrefaction temperature and residence time, while the particle size was reduced, where the lowest mass yield of $40.37 \%$ was obtained under the condition of $320^{\circ} \mathrm{C}, 60 \mathrm{~min}$ and $0.5 \mathrm{~mm}$. This trend shows that increasing both temperature and residence time has a detrimental effect on the mass yield, while the opposite for the particle size. The initial loss of mass is primarily due to loss of inherent moisture due to dehydration and the decomposition of aliphatic compounds [9] from carbohydrates in the food waste. In addition, there is a possible decomposition of hemicellulose and cellulose in
Table 1. Proximate and ultimate analysis of food waste used in this work

\begin{tabular}{lc}
\hline \multicolumn{1}{c}{ Analysis } & Raw FW (\%) \\
\hline Proximate Analysis & \\
Moisture Content (\%ad) & 11.95 \\
Volatile Matter (\%) & 81.00 \\
Fixed Carbon (\%) & 3.77 \\
Ash (\%) & 3.28 \\
HHV (MJ/kg) & 19.67 \\
\hline Ultimate Analysis & \\
Carbon (\%) & 44.61 \\
Hydrogen (\%) & 7.34 \\
Oxygen (\%) & 44.16 \\
Nitrogen (\%) & 3.48 \\
Sulfur (\%) & 0.40 \\
\hline
\end{tabular}

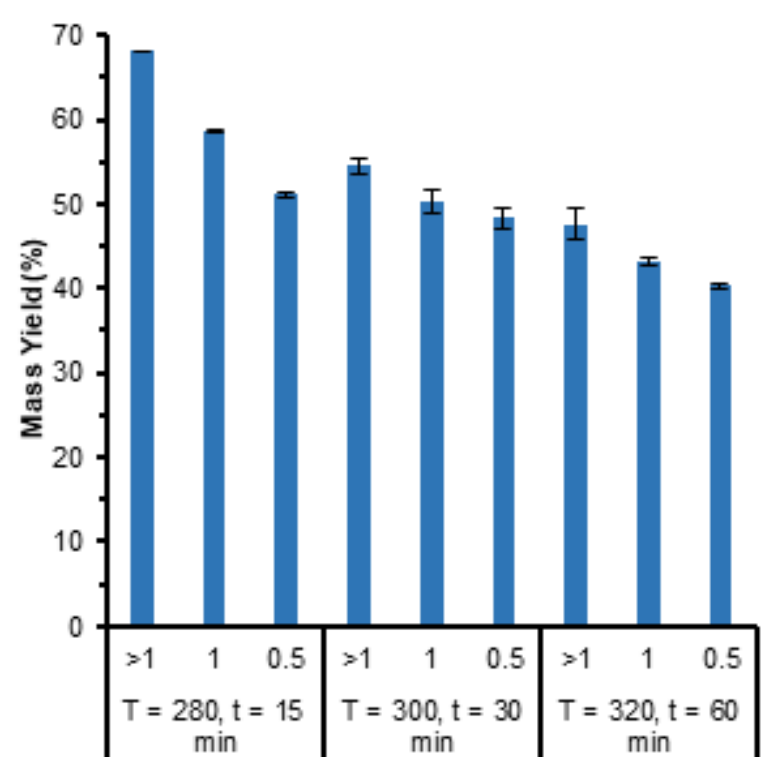

Fig 2. The effects of temperature, residence time and particle size on mass yield

the initial mass loss. Further increase in the torrefaction temperature resulted in a more profound decrease in mass due to depolymerization and released of volatile matters. This could be further enhanced by the degradation of a lignocellulosic fraction of the food waste sample [10].

During the experimental runs, it was also observed that the process also produced brown and black tar-like substances that condensed in the tube. However, they were not quantified. This can be linked to the decomposition and released of higher hydrocarbons at 
higher torrefaction temperatures [9]. The most appropriate or optimum torrefaction temperature, however, cannot be chosen based on mass yield alone, as the torrefaction is linear in trend. The subsequent analysis must be done, such as the proximate analysis, ultimate analysis and HHV of the produced biochar to determine if the torrefied biomass produced has been improved during the process.

\section{Proximate Analysis}

Proximate analysis of the raw and torrefied food waste was analyzed to evaluate the physical changes that occurred during the torrefaction process. Fig. 3 illustrates the progression of volatile matter, fixed carbon, moisture content and ash at various torrefaction temperatures, residence times, and particle sizes. The food waste samples were analyzed as a dried basis; hence its moisture content has been reduced, which means that they are mainly made of volatile matter as shown in the figures.

In Fig. 3(a), it can be observed that the volatile matters were reduced as the torrefaction temperature increased, and it is more profound at the highest temperature of $320^{\circ} \mathrm{C}$ where it is $49.1 \%$ compared to the raw sample that has $81 \%$ volatile matter, which is $39.4 \%$ reduction. A similar trend can be observed for the samples moisture content, where they were reduced with increasing temperature. The highest torrefaction temperature of $320^{\circ} \mathrm{C}$ yields the lowest torrefied sample moisture content of $4.76 \%$, compared to the raw sample
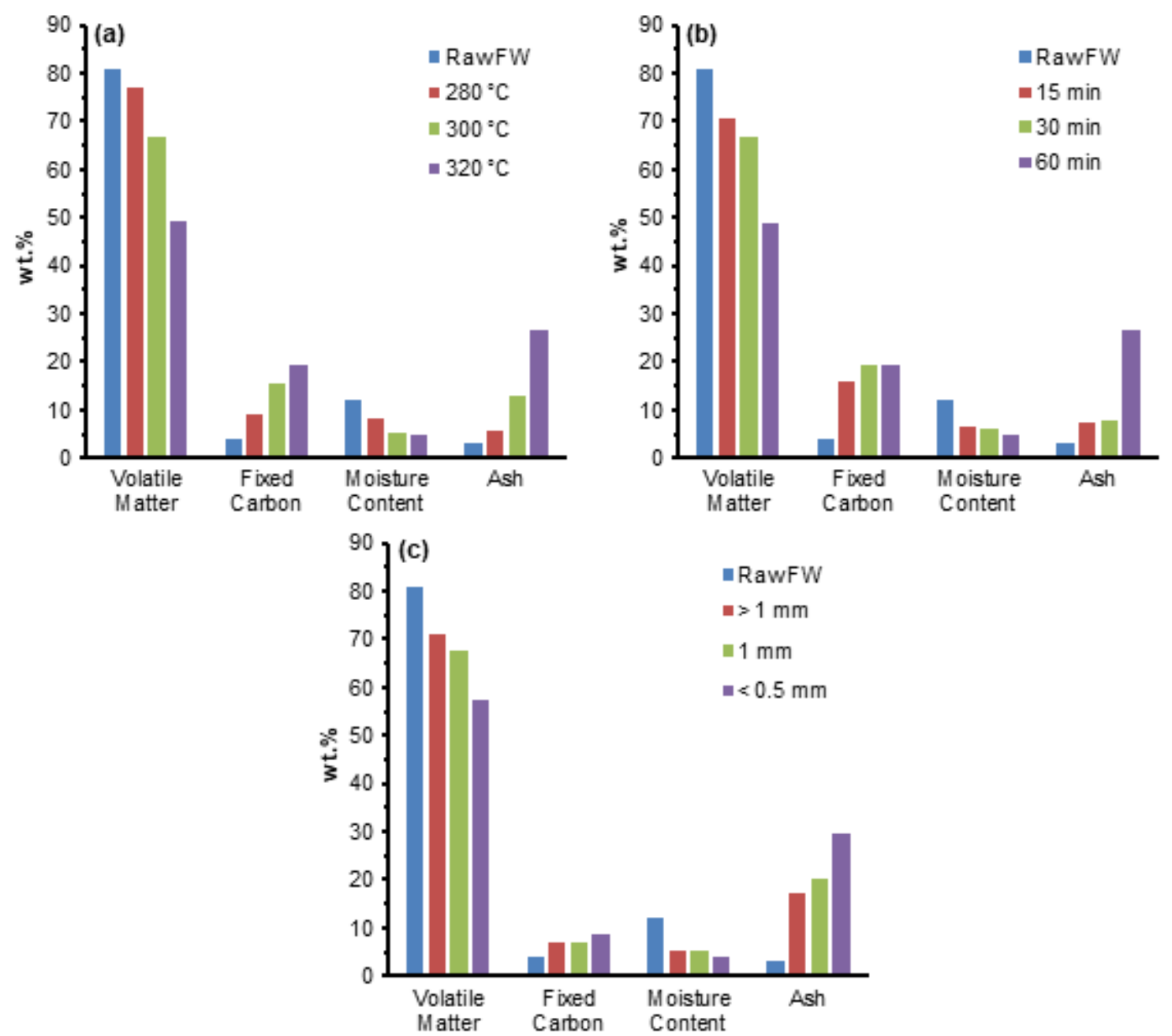

Fig 3. Evolution of volatile matter, fixed carbon, moisture content and ash at various (a) Temperature, (b) Residence time, and (c) Particle size 
with $11.95 \%$. That is in fact $60.2 \%$ reduction in moisture and may also be viewed as an improvement on the solid properties. On the other hand, the fixed carbon and ash increased steadily, with the rise of the torrefaction temperature as seen in the figure. Initial fixed carbon was a mere $3.77 \%$, which increases to $9.18,15.32$, and $19.47 \%$ when torrefied at 280,300 and $320{ }^{\circ} \mathrm{C}$ respectively. Although the actual numbers seem quite small, the improvement is quite significant for fixed carbon, as it increased by 4 -fold at the highest torrefaction temperature.

The decreased of both moisture content, and volatile matter contributed to the significant weight loss that was related to the obtained mass yield. The exposure to torrefaction temperatures has caused the moisture to be released initially, followed by a fraction of the volatile matter due to the vaporization of oxygen-containing molecules [11]. In addition, this may also be attributed to the partial thermal decomposition of biopolymers made of cellulose, hemicellulose, and lignin [12] from the organic fraction of the food waste.

These factors may also have influenced the increased in both fixed carbon and ash content, which is highly desirable as high FC in torrefied biomass will have a considerable contribution to thermal energy release when it is utilized. The results could probably have contributed by fish bones and chicken bones that presented in the sample. Waste fish and chicken bones are characterized with high ashes content which composed of calcium phosphate and carbonate compounds; during torrefaction, these contents have contributed towards the formation of ash, thus resulting in high ash content of the torrefied product [13].

A similar trend can be observed for increasing torrefaction residence time (Fig. 3(b)) and decreasing the particle size (Fig. 3(c)). The longer residence time has a similar effect as the increasing torrefaction temperature. This can be seen in Fig. 3(b), for the reduction of volatile matter and moisture content, and the increased of fixed carbon and ash content, all of which has similar improvement as when the samples were subjected to increasing temperature. They were improved at $39.5 \%$, $59 \%$ and 4 -fold for the volatile matter, moisture content and fixed carbon respectively.
The decreasing particle size also caused consistent improvement for the volatile matter, moisture content and fixed carbon, though at a lesser extent, as shown in Fig. 3(c). The smaller particle size has a larger surface area to ensure effective heat transfer and for the release of moisture and a fraction of volatile matter that is more prone to thermal degradation. These results are consistent with the literature [12], wherein smaller particles, the mass loss is mainly due to the release of a lighter and more volatile compound such as hemicellulose, while for larger particles, the volatile matter will be unable to escape as easily from the center of the particle.

\section{Ultimate Analysis}

The results of the effect of temperature, residence time and particle size on UA of raw and torrefied FW samples are listed in Table 2, whereby $\mathrm{C}, \mathrm{H}, \mathrm{O}, \mathrm{N}$ and $\mathrm{S}$ are the main elements in biomass which have their contributions in the characteristics of biomass. The table also shows the UA of coal as a comparison. The C content at different torrefaction temperatures shows an increasing trend as the temperature increases. At the lowest temperature, the result obtains $50.67 \mathrm{wt}$.\% whereas, at the highest temperature of $320^{\circ} \mathrm{C}$, it is $59.06 \mathrm{wt} . \%$, still far from the $\mathrm{C}$ content of the reference coal which is 84.73 wt.\%. Despite that, the C content still emits a positive trend with the increase of torrefaction temperature. On the other hand, the $\mathrm{H}$ content shows a decreasing trend with temperature increase.

The $\mathrm{H}$ contents are subjected to $7.17 \mathrm{wt} . \%$ at $280^{\circ} \mathrm{C}$, and it achieves the lowest value of $6.26 \mathrm{wt} . \%$ at $320^{\circ} \mathrm{C}$, although it is still higher compared with bituminous coal which is $4.38 \mathrm{wt} . \%$. Similarly, the O content also shows a decreasing trend with the rise of torrefaction temperature as observed in Table 2. The $\mathrm{O}$ content is lowest at $320^{\circ} \mathrm{C}$ with 29.00 wt.\% compared to $300^{\circ} \mathrm{C}$ and $280{ }^{\circ} \mathrm{C}$ which are 29.84 and $37.60 \mathrm{wt} . \%$, respectively. Decreasing of the $\mathrm{O}$ content in the torrefied product results from the carbonization, and the partial release of volatiles during torrefaction which causes the increasing of $\mathrm{C}$ content as temperature increased, as reported by other researchers $[4,14]$. In addition, the decrease in the 
Table 2. Ultimate analysis of raw and torrefied food wastes at a different temperature, time and size

\begin{tabular}{cccccccc}
\hline Temperature $\left({ }^{\circ} \mathbf{C}\right)$ & $\mathbf{C}$ & $\mathbf{H}$ & $\mathbf{O}$ & $\mathbf{N}$ & $\mathbf{S}$ & O/C Ratio & H/C Ratio \\
\hline Raw & 44.61 & 7.34 & 44.16 & 3.48 & 0.40 & 0.99 & 0.16 \\
280 & 50.67 & 7.17 & 37.60 & 4.26 & 0.30 & 0.74 & 0.14 \\
300 & 58.57 & 6.58 & 29.84 & 4.84 & 0.17 & 0.51 & 0.11 \\
320 & 59.06 & 6.26 & 29.00 & 5.53 & 0.15 & 0.49 & 0.11 \\
\hline Time (min) & $\mathbf{C}$ & $\mathbf{H}$ & $\mathbf{O}$ & $\mathbf{N}$ & $\mathbf{S}$ & $\mathbf{O}$ /C Ratio & H/C Ratio \\
\hline 15 & 58.00 & 6.42 & 30.17 & 5.26 & 0.15 & 0.52 & 0.11 \\
30 & 58.31 & 6.29 & 29.70 & 5.56 & 0.14 & 0.51 & 0.11 \\
60 & 59.02 & 5.16 & 28.63 & 7.05 & 0.14 & 0.49 & 0.09 \\
\hline Particle Size $(\mathbf{m m})$ & $\mathbf{C}$ & $\mathbf{H}$ & $\mathbf{O}$ & $\mathbf{N}$ & $\mathbf{S}$ & $\mathbf{O} / \mathbf{C}$ Ratio & H/C Ratio \\
\hline$>1$ & 53.93 & 6.39 & 34.10 & 5.41 & 0.17 & 0.63 & 0.12 \\
1 & 59.06 & 6.26 & 29.00 & 5.53 & 0.15 & 0.49 & 0.11 \\
0.5 & 61.90 & 6.05 & 25.66 & 6.25 & 0.14 & 0.41 & 0.10 \\
\hline Coal $[9]$ & 84.73 & 4.38 & 8.46 & 1.99 & 0.44 & 0.10 & 0.05
\end{tabular}

$\mathrm{H}$ and $\mathrm{O}$ contents may also be attributed to the degradation of a hydroxyl group $(-\mathrm{OH})$ in the food waste samples during torrefaction. This, in turn, produced solid fuel that is hydrophobic [15].

Apart from that, $\mathrm{N}$ is one of the important elements in biomass. From the table, it can be observed that the $\mathrm{N}$ content indicates an increasing trend as temperature increases. Based on the results, the lowest temperature results in 4.26 wt.\% whereas the highest temperature accounts for 5.53 wt.\% of the $\mathrm{N}$ content, although still higher in comparison to coal which has only $1.99 \mathrm{wt} . \%$. In this context, $\mathrm{N}$ content is one of the elements presented in the protein of the food waste sample which may be the reason for the lower value of $\mathrm{N}$ content in the coal compared to the raw FW and torrefied FW [4]. Similar result trends were also reported by Sabil et al. [16].

The increase in residence time produces torrefied biomass products that have the same characteristics with the ones subjected to temperature increase, whereby the $\mathrm{C}$ content was also increased, while the $\mathrm{H}$ and $\mathrm{O}$ content was decreased. It is apparent that longer residence time has similar effects as increased torrefaction temperature, whereby it allows for the dehydration and carbonization to occur more profoundly [14]. This is, however, has the opposite effects when the particle size was increased. As shown in Table 2, decreasing of food waste particle size will increase the $\mathrm{C}$ content, while decreasing the $\mathrm{H}$ and $\mathrm{O}$ content. This may be due to the increased surface area of the solid particles, exposed to the imminent heat in the torrefaction process. The increased surface area allows for more moisture and volatile matter removal.

A Van Krevelen plot is shown in Fig. 4 to demonstrate the change in the elemental ratio of $\mathrm{H} / \mathrm{C}$ as a function of the $\mathrm{O} / \mathrm{C}$ ratio. The elemental ratios denote the measures of pyrolysis efficiency and oxidation degree of torrefied products [17], whereby lower values will exhibit coal-like properties. Fig. 4 shows that the elemental composition of torrefied food waste that moves

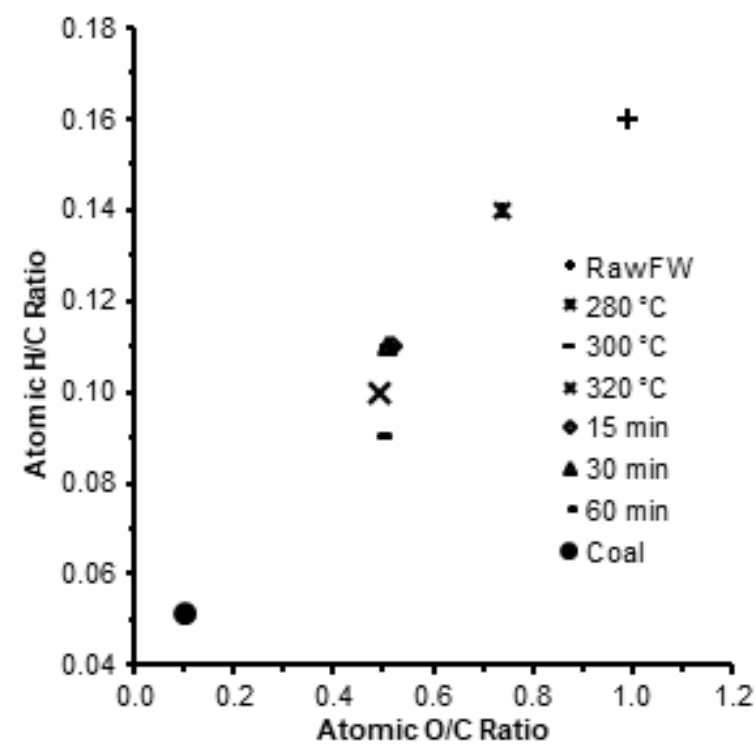

Fig 4. Van Krevelen plot of raw and torrefied food waste samples at various temperature, residence time, particle size 
towards coal, with the best result is obtained from torrefaction of food waste at $320^{\circ} \mathrm{C}, 60 \mathrm{~min}$ and $0.5 \mathrm{~mm}$. The results are in accord with numerous literature that has reported that torrefied biomass possesses characteristics close to or similar to the coal [18-21].

\section{Higher Heating Value (HHV)}

The heating value of biomass is the amount of energy produced by the complete combustion of the biomass, an important indicator of solid fuel quality. It is measured by using the results of weight percentages of element $\mathrm{C}, \mathrm{H}, \mathrm{N}, \mathrm{S}$, and $\mathrm{O}$ obtained from CHNS Element Analyzer. It is calculated based on Eq. 1. The results of the effect of temperature, residence time and particle size on the heating value of raw and torrefied are listed in Table 3.

It can be observed from the table that as the torrefaction temperature intensifies, the higher heating value increases. The heating value of raw $\mathrm{FW}$ sample is $19.63 \mathrm{MJ} / \mathrm{kg}$. However, after being torrefied at $280^{\circ} \mathrm{C}$, the heating value increases to $21.82 \mathrm{MJ} / \mathrm{kg}$, which is an $11 \%$ improvement. It further increased to 24.35 to $24.45 \mathrm{MJ} / \mathrm{kg}$ when torrefied at 300 and $320^{\circ} \mathrm{C}$ respectively, which are

Table 3. The effects of temperature, residence time and particle size on the higher heating value

\begin{tabular}{|c|c|c|c|}
\hline $\begin{array}{c}\text { Temperature } \\
\left({ }^{\circ} \mathrm{C}\right)\end{array}$ & $\begin{array}{c}\text { HHV } \\
(\mathrm{MJ} / \mathrm{kg})\end{array}$ & $\mathbf{T}_{\mathrm{d}}$ & $\begin{array}{c}\% \\
\text { Improvement }\end{array}$ \\
\hline Raw FW & 19.63 & & \\
\hline $280^{\circ} \mathrm{C}$ & 21.82 & 1.1116 & 11.16 \\
\hline $300^{\circ} \mathrm{C}$ & 24.35 & 1.2404 & 24.04 \\
\hline $320^{\circ} \mathrm{C}$ & 24.45 & 1.2455 & 24.55 \\
\hline $\begin{array}{l}\text { Time } \\
(\mathrm{min})\end{array}$ & $\begin{array}{c}\text { HHV } \\
(\mathrm{MJ} / \mathrm{kg})\end{array}$ & $\mathbf{T}_{\mathrm{d}}$ & $\begin{array}{c}\% \\
\text { Improvement }\end{array}$ \\
\hline Raw FW & 19.63 & & \\
\hline 15 & 23.21 & 1.1824 & 18.24 \\
\hline 30 & 24.39 & 1.2425 & 24.25 \\
\hline 60 & 24.48 & 1.2471 & 24.71 \\
\hline $\begin{array}{c}\text { Particle Size } \\
(\mathbf{m m})\end{array}$ & $\begin{array}{c}\text { HHV } \\
(\mathrm{MJ} / \mathrm{kg})\end{array}$ & $\mathbf{T}_{\mathrm{d}}$ & $\begin{array}{c}\% \\
\text { Improvement }\end{array}$ \\
\hline Raw $>1$ & 19.67 & & \\
\hline$>1$ & 22.62 & 1.1500 & 15.00 \\
\hline Raw 1 & 19.63 & & \\
\hline 1 & 24.89 & 1.2680 & 26.80 \\
\hline Raw 0.5 & 20.97 & & \\
\hline 0.5 & 25.82 & 1.2313 & 23.13 \\
\hline
\end{tabular}

$24 \%$ improvement in comparison to the original, untreated food waste. This consistent increase may be attributed to the enrichment of $\mathrm{C}$ content due to carbonization of FW that occurs during torrefaction, similar to findings from previous researchers [19]. The results obtained are also in range, at which HHV of the raw biomass is between 15 to $20 \mathrm{MJ} / \mathrm{kg}$ whereas the torrefied biomass is between 16 to $29 \mathrm{MJ} / \mathrm{kg}$ [22].

The increase in residence time as shown in Table 3, increases the heating value, between $18-24 \%$ improvements in comparison to the untreated food waste. Similar to the UA, it can be observed that longer residence time has similar effects as increased torrefaction temperature, whereby it allows for more severe dehydration and carbonization to occur. Interestingly, the improvement of the heating values is higher compared to when the torrefaction was subjected to increase, suggesting that the heating values are more affected by the torrefaction residence time. The degree of torrefaction is also increased with increased torrefaction temperature, longer residence time and smaller particle size, which indicates the increased of energy gained.

\section{- CONCLUSION}

In conclusion torrefied food waste has increased $\mathrm{C}$ content, lower $\mathrm{H}$ and $\mathrm{O}$ contents, increased higher heating value and improved the degree of torrefaction, which means better combustion characteristics. The results obtained from this work suggests that torrefaction is an effective pre-treatment method and the torrefied food waste has to potential to be utilized as a solid renewable biofuel. On the other hand, is an endothermic process, the energy requirement for this torrefaction process should also be studied, to ensure that not only that it solves the environmental issues related to the filling up of the landfill, it is also economically attractive.

\section{- ACKNOWLEDGMENTS}

The authors are grateful to the Universiti Malaysia Pahang and Faculty of Chemical and Natural Resources Engineering for financial support (RDU1803110). This work is also in collaboration with Mercu Resolution Sdn Bhd. 


\section{- REFERENCES}

[1] Zainu, Z.A., and Songip, A.R., 2017, Policies, Challenges and Strategies for Municipal Waste Management in Malaysia, JOSTIP, 3 (1), 18-22.

[2] The Star, 2016, Malaysians waste 15,000 tonnes of food daily, https://www.thestar.com.my/news/nation/ 2016/05/24/malaysians-waste-15000-tonnes-of-fooddaily/, accessed on February 8, 2018.

[3] Matsakas, L., Gao, Q., Jansson, S., Rova, U., and Christakopoulos, P., 2017, Green conversion of municipal solid wastes into fuels and chemicals, Electron. J. Biotechnol., 26, 69-83.

[4] Poudel, J., Ohm, T.I., and Oh, S.C., 2015, A study on torrefaction of food waste, Fuel, 140, 275-281.

[5] Jo, J.H., Kim, S.S., Shim, J.W., Lee, Y.E., and Yoo, Y.S., 2017, Pyrolysis characteristics and kinetics of food wastes, Energies, 10 (8), 1191.

[6] Samad, N.A.F.A., Jamin, N.A., and Saleh, S., 2017, Torrefaction of municipal solid waste in Malaysia, Energy Procedia, 138, 313-318.

[7] Ghassemi, H., Beheshti, S.M., and ShahsavanMarkadeh, R., 2015, Mathematical modeling of extraheavy oil gasification at different fuel water contents, Fuel, 162, 258-263.

[8] Karki, S., Poudel, J., and Oh, S.C., 2018, Thermal pretreatment of sewage sludge in a lab-scale fluidized bed for enhancing its solid fuel properties, Appl. Sci., 8 (2), 183.

[9] Pahla, G., Ntuli, F., and Muzenda, E., 2018, Torrefaction of landfill foodwaste for possible application in biomass co-firing, Waste Manage., 71, 512-520.

[10] Gong, C., Huang, J., Feng, C., Wang, G., Tabil, L., and Wang, D., 2016, Effects and mechanism of ball milling on torrefaction of pine sawdust, Bioresour. Technol., 214, 242-247.

[11] Chin, K.L., H'ng, P.S., Go, W.Z., Wong, W.Z., Lim, T.W., Maminski, M., Paridah, M.T., and Luqman, A.C., 2013, Optimization of torrefaction conditions for high energy density solid biofuel from oil palm biomass and fast growing species available in Malaysia, Ind. Crops Prod., 49, 768-774.
[12] Rossini, G., Toscano, G., Duca, D., Corinaldesi, F., Pedretti, E.F., and Riva, G., 2013, Analysis of the characteristics of the tomato manufacturing residues finalized to the energy recovery, Biomass Bioenergy, 51, 177-182.

[13] Darwish, M., Aris, A., Puteh, M.H., Jusoh, M.N.H., and Kadir, A.A., 2016, Waste bones ash as an alternative source of $\mathrm{P}$ for struvite precipitation, $J$. Environ. Manage., 203 (Part 2), 861-866.

[14] Bridgeman, T.G., Jones, J.M., Shield, I., and Williams, P.T., 2008, Torrefaction of reed canary grass, wheat straw and willow to enhance solid fuel qualities and combustion properties, Fuel, 87 (6), 844-856.

[15] Phanphanich, M., and Mani, S., 2011, Impact of torrefaction on the grindability and fuel characteristics of forest biomass, Bioresour. Technol., 102 (2), 1246-1253.

[16] Sabil, K.M., Aziz, M.A., Lal, B., and Uemura, Y., 2013, Effects of torrefaction on the physiochemical properties of oil palm empty fruit bunches, mesocarp fiber and kernel shell, Biomass Bioenergy, 56, 351-360.

[17] Cellatoğlu, N., and İlkan, M., 2015, Torrefaction of solid olive mill residue, Bioresources, 10 (3), 58765889.

[18] Tumuluru, J.S., 2015, Comparison of chemical composition and energy property of torrefied switchgrass and corn stover, Front. Energy Res., 3, 46.

[19] Gucho, E.M., Shahzad, K., Bramer, E.A., Akhtar, N.A., and Brem, G., 2015, Experimental study on dry torrefaction of beech wood and miscanthus, Energies, 8 (5), 3903-3923.

[20] Ibrahim, R.H.H., Darvell, L.I., Jones, J.M., and Williams, A., 2013, Physicochemical characterisation of torrefied biomass, J. Anal. Appl. Pyrol., 103, 21-30.

[21] Wilk, M., Magdziarz, A., Kalemba, I., and Gara, P., 2016, Carbonisation of wood residue into charcoal during low temperature process, Renewable Energy, $85,507-513$.

[22] Chen, W.H., 2015, "Torrefaction" in Pretreatment of Biomass, Eds., Pandey, A., Negi, S., Binod, P., and Larroche, C., Elsevier B.V., Amsterdam, Netherlands, 173-192. 